\title{
The Normative Foundations of Emancipatory Theory: Evolutionary versus Pragmatic Perspectives ${ }^{1}$
}

\author{
Robert J. Antonio \\ University of Kansas
}

From the start, emancipatory theory has been plagued by contradictory and incompletely elaborated normative underpinnings that weaken its sociological and ethical credibility. Jürgen Habermas, the leading contemporary critical theorist, has attempted to address this problem in an extensive reconstruction of the theories of Marx and Weber that appropriates elements of American pragmatist thought. Yet he resorts to an evolutionary normative argument that undermines the sociological powers of the two classical theories and contradicts the pragmatists' historical approach to values. This essay explains the significance of Habermasian theory for the emancipatory tradition, analyzes certain problems of the theory, and argues that an expanded dialogue with American pragmatism would strengthen both its sociological and its normative dimensions. Though the explicit focus is on the emancipatory tradition, the essay raises broader critical questions about pseudohistorical, normative justification in general sociological theory.

The relation of fact to value has long been a central problem in the social sciences and a particularly controversial issue for partisan approaches that advocate sweeping social transformations. Since its inception during the Enlightenment, "critical" sociology has faced difficult questions about

\footnotetext{
${ }^{1}$ I have benefited substantially from critical exchanges about this material with Douglas Kellner, Robert Kent, Harold L. Orbach, and Lawrence A. Scaff and from the incisive criticism of three anonymous $A J S$ reviewers. Critical comments on earlier drafts by Gisela Hinkel, Stephen Kalberg, Scott MacNall, George Ritzer, and Alan Sica and by Jean Cohen in response to an oral presentation were also helpful. Finally, I am grateful to Pat Johnston for her assistance on several drafts of the manuscript. Earlier versions were presented at the meetings of the American Sociological Association in New York, August 1986, and at the Max Weber Colloquium (Max Weber and the Politics of Left and Right) in Wayne, N.J., November 16, 1986. This research was supported by University of Kansas general research grant allocation 3627-XO-0038. Requests for reprints should be sent to Robert J. Antonio, Department of Sociology, University of Kansas, Lawrence, Kansas 66045.
}

(C) 1989 by The University of Chicago. All rights reserved. 0002-9602/89/9404-0001\$01.50 
the grounding of the value positions that orient its critiques. Without rationally justified normative foundations, evaluations of "exploitative" or "oppressive" social conditions and prescriptions for "emancipatory" social change seemed arbitrary.

But under the disenchanted conditions of modernity, direct appeals to a priori valuative "truth" (ethical "rightness") have been discredited within most critical intellectual circles. Consequently, in defense of their orienting values, social theorists have often supplanted religious and philosophical absolutism ${ }^{2}$ with evolutionary claims about normative validity. ${ }^{3}$ Evolutionary justification upholds values on the basis of their correspondence with an allegedly progressive direction of historical development (e.g., toward market society or toward socialism) and implies that these values would be experienced as universally binding under the demystified social conditions of a "higher" historical stage. The hypothetical value consensus and theoretical collective subject justify efforts to usher in the new historical stage. This pseudohistorical defense of value is an incompletely secularized version of absolutism and, like the earlier foundationalist arguments, presumes normative grounds outside critical dialogue.

Pragmatic arguments can often be found alongside evolutionary claims about universal normative validity and universal consensus. ${ }^{4}$ But in this

${ }^{2}$ Absolutism refers to positions that make claims about ultimate truths and ultimate realities beyond sense experience and scientific inquiry. These positions depend upon revelation or rational intuition, or both.

${ }^{3}$ Evolutionary normative arguments have not been monopolized by leftist thinkers. For example, Émile Durkheim ([1893] 1964, pp. 374-88) provided an evolutionary basis for equal opportunity, liberty, and social justice, and Talcott Parsons ([1966/ 1971] 1977, pp. 182-241) defended the modern American versions of these liberal values in a similar fashion. Likewise, Herbert Spencer and William Graham Sumner defended laissez-faire on evolutionary grounds, as does the leading modern proponent of this tradition, F. A. Hayek (Hayek 1983; Gray 1984, pp. 41-55; Antonio 1987).

${ }^{4}$ Foundationalist universalism, as expressed either in evolutionary normative arguments or in ethical absolutism, must be distinguished from the modest and defensible universalism inherent in any consistent ethical vision-i.e., moral action is based on "objective" considerations beyond fleeting individual desires and invokes principles ("good reasons") that apply in all like cases. Pragmatist ethics embraces this modest form of universalism. Conversely, foundationalists argue for a much more comprehensive universality that endows norms with binding transcultural and transhistorical moral authority. Most important, they seek to escape relativism by establishing an ultimate normative "ground" or "foundation" to orient historical valuation. This distinction is crucial because foundationalist moralists contend that the first type of universalism is impossible without the comprehensive form and, consequently, equate historicist ethics with moral relativism or nihilism. I follow the American pragmatists, who argued that moral principles and moral actions do not require knowledge of what is right across cultural and historical contexts. See Arthur Edward Murphy (1965, pp. 271-352) and John Dewey and James Hayden Tufts ([1932] 1985, pp. 275-83) for incisive criticism of foundationalist universalism. 
case, normative justification derives from a value's ability to hold sway in social dialogues about societal institutional arrangements, about the capacity of these arrangements to meet the needs of community members, and about the various empirical conditions that bear on these matters. In these dialogues, traditional normative symbols are reformulated to address existing social conditions, needs, and possibilities for change. Finally, the emergent moral understandings are not end points but, instead, constitute moments of an ongoing social dialogue that leads to still newer understandings. Although it appears implicitly in many varieties of social theory, the American pragmatists have expressed this communicative ideal most directly and comprehensively. The pragmatist broadside against foundationalism makes emphatically clear their view that normative validity rests exclusively on the secular grounds of culturally specific, intersubjective understandings that arise within historical communication communities.

Most of this essay focuses on the thought of Jürgen Habermas. As I will demonstrate below, emancipatory theory, ${ }^{5}$ from the start, has been plagued by contradictory and incompletely elaborated normative underpinnings that undermine its sociological and ethical credibility. Habermas traces the root of this problem to Karl Marx but also contends that critical theorists' efforts to shore up emancipatory theory with ideas from Max Weber did not improve matters. In his view, neither classical theorist elaborated the grounds of his normative standpoints, and to make up this deficit, Habermas incorporates the pragmatists' communicative ideal into the heart of his own theory. Yet in elaborating his intersubjective approach to normative justification, Habermas resorts to evolutionary argumentation and quasi-foundationalist universalism, ${ }^{6}$ which diminish

\footnotetext{
${ }^{5}$ Emancipatory theory refers to the broader Hegelian-Marxian tradition of theorizing, whereas critical theory designates the strain that began with the Frankfurt School in the 1920s and continues today in different types of research and theory. Both approaches contain numerous heterodoxies and escape simple definition. See Martin Jay $(1973,1984 a)$ for fairly comprehensive intellectual histories of the two traditions.

${ }^{6}$ Habermas ([1981] $1987 c$, pp. 396-403) seeks a nonrelativistic normative foundation for emancipatory theory but, at the same time, wants to derive it from actual social life and to be able to defend it on scientific as well as intuitive grounds. By calling it quasifoundationalist, I mean that, contrary to classical religious and philosophical foundationalism, Habermas's position does not rest on a priori claims, which are, in principle, beyond empirical inquiry. Habermas must reject classical foundationalism because it contradicts his effort to put emancipatory theory on a purely intersubjective basis open to consensual validation. But, as I will explain below, the dividing line between the two positions is not that great, and, despite Habermas's analytic qualifications and affirmations of value pluralism, his core normative argument tends toward the foundationalist universalism described above in $\mathrm{n} .4$ and, consequently, breaks with pragmatist ethics.
} 
the sociological powers of emancipatory theory and contradict his fusion of pragmatism and critical theory.

\section{THE DUAL ORIGIN OF EMANCIPATORY THEORY: EVOLUTIONARY VERSUS HISTORICAL IMMANENT CRITIQUE}

Emancipatory theorists have argued that superordinate social strata, since the Enlightenment, have justified their dominance with democratic legitimations and that emancipatory movements have arisen in response to these unfulfilled normative claims. Their Hegelian-Marxist "immanent critique" was supposed to side with the normative standpoints of social movements (or potential social movements) that struggle to reduce exploitation, coercion, and inequality and, therefore, to close the gap between Enlightenment values and social reality (Jay 1973, p. 63; Schroyer 1975, pp. 27-37; Guess 1981, pp. 26-44, 55-63; Antonio 1981, 1983). Marx employed two types of immanent critique that became the basis for sharply different modes of "emancipatory" theorizing. ${ }^{\text {" }}$

Marx argued that advancing productive forces generate a sequence of class struggles, producing ascending "historical" stages (i.e., tribal, ancient, feudal, and capitalist modes of production) and culminating in a rational terminus to human "prehistory" (communism). ${ }^{8}$ Temporally experienced needs and empirical conditions that contradict the evolutionary pathway are dismissed as "false consciousness" or as temporary sidetracks incapable of derailing the transhistorical motor force. Here, the emancipatory normative standard is "validated" by a nonfalsifiable evolutionary metalogic beyond social dialogue.

Conversely, Marx also criticized early capitalist society from the perspective of its own bourgeois values of freedom, democracy, and plenty. Moreover, he concluded, on the basis of his reading of determinate historical conditions, that developmental tendencies of early capitalism were not only intensifying exploitation and misery but were also strengthening the social bonds among the growing mass of wage laborers and creating

\footnotetext{
7 Although they can be distinguished analytically, they are not always separated in Marx's texts. Marx used elements of his historical immanent critique of early capitalism in his evolutionary materialism, and the reverse.

${ }^{8}$ Marx mentioned these stages of history briefly (e.g., see Marx and Engels [1845-46] 1964, pp. 27-95; Marx [1859] 1970, pp. 20-22). As William H. Shaw (1978, pp. 11415) points out, capitalist development was Marx's overarching interest, and he framed the precapitalist modes of production from this viewpoint (also, see Cohen 1978; McMurtry 1978; Rader 1979). However, there is another side to Marx's materialist epistemology that is methodologically defensible and is not reducible to his teleological stages of history (e.g., see Ste. Croix 1984; Ste. Croix 1981, pp. 31-111). Finally, Habermas ([1976] 1979a; Habermas [1976] 1979b, pp. 130-77) has commented critically on Marx's evolutionary materialism.
} 
the means to satisfy their unmet needs. On this basis, he reconstructed bourgeois values into a more oppositional normative standard, representing the nascent standpoint of the proletarian movement. Questions about the long-term accuracy of this scenario are beside the point. In contrast to his evolutionary teleology, the bold claims of Marx's historical argument were open to empirical investigation and critical debate. Here, normative justification depended on whether the portrayals of societal contradictions and of unmet needs expressed accurately the primary tensions of the historical conjuncture and, on this basis, whether the values in question would gain a wider hold on public consciousness and generate emancipatory struggles that would reshape institutional arrangements accordingly.

Despite the openness of his historical immanent critique, Marx never elaborated its underlying pragmatic grounds, nor did he express awareness of the problematic nature of achieving intersubjective understandings. On the contrary, he spoke as if normative truth and social reality were transparent to the materialist and that, in the absence of "fetishism" and "false consciousness," the brute facticity of the contradiction between bourgeois values and reality would be readily apparent, as would be the means for its overcoming. Even in his historical immanent critique, Marx failed to consider adequately the patterns of communication and bases of intersubjective agreement necessary for the rise of an emancipatory proletariat (see Sherover-Marcuse 1986), and this problem would long plague the emancipatory theory tradition.

\section{PESSIMISTIC CRITICAL THEORY} AND HABERMAS'S PROBLEMATIC

The two normative arguments in Marx's writings later were expressed in separate Marxist traditions. The crude evolutionary arguments of official Marxists insisted that the materialist metalogic operated beneath the phenomenal forms of modern society, guaranteeing eventual delivery to the promised land of emancipation. Their Stalinist "diamat" (dialectical materialism) validated the power of the party by demanding unconditional acceptance of its ultimate normative ends. Western Marxists, however, responded to changing historical conditions and began to rethink Marx's political project (see Jay 1984a; Gouldner 1980).

At first, critical theorists believed that the contradiction between Enlightenment values (i.e., freedom, democracy, and plenty) and capitalist socioeconomic organization still contained seeds of an emancipatory transformation, and thus they retained a strong, underlying Marxist framework (Dubiel [1978] 1985, pp. 11-67; Held 1980, pp. 29-76). But their historical immanent critique led them eventually to abandon most of 
the substance of Marx's theory. To confront the new types of corporate capitalist and totalitarian regimes, critical theorists borrowed heavily from Max Weber's theories of rationalization and bureaucratization and wove them into their own increasingly pessimistic vision of a "totally administered society" (see Kellner 1985; Benhabib 1986, pp. 182-85). Under the dark clouds of fascism and Stalinism, they came to believe that critical theory, at best, provided a theoretical sanctuary to preserve oppositional values until the rise of new historical conditions (Dubiel 1985, pp. 69-97; Benhabib 1986, pp. 147-85; Wolin 1987).

After World War II, capitalist abundance divided and depoliticized the working class, postponing indefinitely the arrival of the emancipatory proletariat. Critical theorists contended that consumer society emptied bourgeois values of oppositional content and transformed them into a "one-dimensional" legitimation of possessive individualism (e.g., see Marcuse 1964). Because they considered the cultural basis for historical immanent critique to be defunct, postwar critical theorists shifted to a politically disengaged critique of Enlightenment rationalism and a philosophical defense of critical thought. In their "dialectic of Enlightenment" phase, most critical theorists abandoned both Marxism and its ideal of class emancipation (e.g., see Horkheimer [1947] 1974; Horkheimer and Adorno [1944] 1969; Adorno [1966] 1973).

Jürgen Habermas wanted to revive the Enlightenment project that critical theorists had left behind (Habermas 1981a; Habermas 1985a, pp. 75-79; Jay 1984a, pp. 462-509) but could not shed completely their pessimistic cultural critique. He agreed that "bourgeois consciousness has become cynical" and implied that widely accepted oppositional "norms and values to which an immanent critique might appeal" were in eclipse (Habermas 1979b, p. 97). ${ }^{9}$

But despite his doubts about bourgeois morality, Habermas contends that the normative underpinnings for a critical standpoint could be found within the patterns of communication beneath the surface of substantive public dialogue. Critical theorists, however, were oblivious to this takenfor-granted normative dimension because of inherited metatheoretical baggage from Marx and Weber. Although their sociologies contained a vague normative ideal of "broader societal rationality" (e.g., Habermas 1984, pp. 144-45; Habermas 1985b, p. 192), the two classical theorists failed to elaborate its precise shape and explain its intersubjective moor-

'Habermas's portrayal of the erosion of public life (Habermas 1962; Habermas [1964] 1974; Habermas [1968] 1970, pp. 50-122; Hohendahl 1974, 1979) by mass society and technocratic ideology is reminiscent of the older generation's views about "onedimensionality," "total administration," and "the culture industry." These themes still can be detected in revised form in his later work (Habermas [1981] 1984, pp. 396-99; Habermas $1987 c$, pp. 153-97, 303-83). 
ings, leaving them without the necessary perspective to discover the communicative ground of emancipatory norms. Habermas attempts to escape the resignation of pessimistic critical theory by elaborating the approach's repressed normative foundation in a reconstruction of its MarxianWeberian roots.

\section{HABERMAS'S CRITIQUE OF MARX: SPLITTING THE ORGANIZATIONAL AND NORMATIVE DOMAINS}

Since Marx's critical normative stance cannot be elaborated from his materialist epistemology, Habermas ([1968] 1971, pp. 43-63; Habermas $1979 b$, pp. 95-98) starts his reconstructive effort by attacking technological determinism and rejecting the Marxian equation of material progress with social progress. In his view, Marx's "forces of production" and "relations of production" had to be reformulated and the strict subordination of superstructure to base abandoned. Because historical materialism does not distinguish the rationality that governs voluntaristic social relations from that which guides instrumental manipulations of nature, it cannot express adequately the modes of communication and intersubjectivity through which emancipatory values are formulated and gain social consensus (Habermas 1979b, pp. 138-52; Habermas [1963/1971] 1973, pp. 142-69). This prototechnocratic side of Marx's thought affirms the depoliticization and bureaucratization of advanced industrial societies. By equating technological and administrative rationalization with democratization, Marxism forfeits its critical capacities and fails to address the primary normative question of modern emancipatory theory (i.e., "How can the power of technical control be brought within the range of the consensus of acting and transacting citizens?") (Habermas 1970, p. 57).

Habermas "reconstructs" Marxism by rejecting its comprehensive concept of productive-force primacy ${ }^{10}$ and by separating the sphere of technical rules, technical control, and productive forces from that of social norms, human reciprocity, and communication (Habermas 1970, pp. 9194, 113; Habermas 1971, pp. 43-63; Habermas 1973, pp. 142-69; Habermas 1979b, pp. 130-77; Giddens 1982). Labor and interaction are then

10 Though, at first, Habermas (1970, pp. 113-14; Habermas 1973, pp. 168-69) formally accepts the primacy of material factors in societal evolution, he (1979b, p. 146) later states that "the development of productive forces . . . triggers but does not bring about the overthrow of relations of production and evolutionary renewal of the mode of production. But even in this formulation the theorem can hardly be defended. . . ." Habermas ([1985] 1987a, pp. 321-22) softens this position even further in his recent work. Therefore, his "reconstructed" historical materialism bears little resemblance to Marx's version. 
employed to designate the respective domains of organizational rationality and communicative rationality and to replace Marx's materialist concepts of productive forces and relations. The new categories are the intellectual axis of an approach that deviates sharply from the original theory that Habermas wants to rescue. Though his critique of technological determinism is laudable, Habermas's reconstruction also breaks with Marx's dialectical treatment of socioeconomic structure and societal legitimations. The distinction between labor and interaction provides a rationale for treating the organizational and normative spheres as semiautonomous domains with opposed logics of development. ${ }^{11}$ Habermas then looks for critical theory's normative grounding solely in the sphere of interaction and, particularly, in the subtle, universalistic, taken-forgranted attributes of human communication.

\section{HABERMAS'S RECONSTRUCTED WEBER: THE SUNNY SIDE OF DISENCHANTMENT}

Habermas believes that Weber's analysis of cultural rationalization offers a better substantive starting point than Marx's work for clarifying critical theory's underlying conception of "broader societal rationality." Consequently, he refracts the Marxian emancipatory project through a strong Weberian lens. ${ }^{12}$ But in his search for normative underpinnings, Habermas ultimately breaks with Weber almost as sharply as he does with Marx. The differences with Weber derive mostly from Habermas's effort to elaborate a brighter side to disenchantment. Habermas emphasizes a growing capacity for ethical consensus to be separated from material interest, whereas Weber stressed an expanding value conflict mired in an increasingly materialistic worldview. Following an idealist strain in recent German Weber scholarship (see Kalberg 1979), ${ }^{13}$ Habermas con-

\footnotetext{
11 Three qualifications are in order. First, Habermas (1984, pp. 397-99; Habermas $1987 c$, p. 343) acknowledges the role of material interests and does not substitute idealism for materialism. Second, he $(1979 b$, pp. $158-77 ; 1983 ; 1987 a)$ implies, at least, a highly generalized interactive codevelopment of the organizational and normative spheres (e.g., certain features of the abundance and organizational differentiation of modernity foster ethical and communicative rationalization). Finally, Habermas intends to revise, not to abandon, Marxism (see 1987c, pp. 332-96).

${ }^{12}$ Habermas addresses Weber most comprehensively in his study of communicative action (1984, pp. 143-271, 345-65; Habermas 1987c, pp. 303-31). Although he did not previously provide much textual commentary on Weber, strong Weberian influences can be detected in his earlier writings. But Habermas (1985a, p. 77) states that he "first began a more intensive study of Weber" after 1971.

13 These thinkers (e.g., Schluchter 1979, 1981; Tenbruck 1980) do not pose monistic idealist causation or deny the significance of material interests. On the other hand, they do consider the writings on religion as the center of Weber's work (instead of
} 
structs a logic of progressive ethical rationalization from Weber's writings on religion and opposes it to the type of rationalization described in Weber's political sociology and organizational analysis.

The Weberian flavor of Habermas's "reconstruction" of Marx results partly from the fact that he translates the central concepts of labor and interaction into the language of neo-Weberian action theory. Habermas equates labor with purposive-rational action (oriented toward technical rules, control/power, and productive forces) and interaction with communicative action (oriented toward social norms, reciprocity/individuation, and communication free from domination) (1970, pp. 91-94). ${ }^{14}$ But despite the obvious Weberian tone, these action types belong to Habermas and are an important feature of his critique of Weber. Most important, Habermas (1984, pp. 143-44, 172-73, 198, 221-22, 233, 243-71) claims that Weber's heavy emphasis on purposive rationalization (especially economic rationalization and bureaucratization) caused him to neglect elaboration of his implicit normative concept of broader societal rationality and to stop far short of Habermasian communicative rationality. Thus Weber is thrust into Marx's bad company. Both theorists allegedly focused too narrowly on capitalist development and, conse-

Economy and Society), emphasize strongly the broad cultural significance of disenchanted ideas and worldviews, and describe a progressive movement in Western religious rationalization that runs counter to the relativistic, conflictual, and coercive themes of Weber's political sociology. Most important, like Habermas, they imply evolutionary normative justification in their portrayals of ethical rationalization. Also, Habermas has been influenced by Parsons's reading of Weber and his vision of progressive rationalization (though Habermas is critical of the Parsonian tendency to harmonize normative rationalization and organizational rationalization) (see Habermas 1987c, pp. 283-99). Parsons claimed that Weber, like Marx, gave too much emphasis to coercive power and had an overly pessimistic view of rationalization too closely tied to domination and hierarchy. Supposedly, Weber caught this virus by attending too closely to Marx's problematic (Parsons [1937] 1968, pp. 510, 658, 75253; Parsons 1949, pp. 115-16; Parsons 1960, pp. 182, 219-20; Parsons [1947] 1964, pp. 58-60 n. 4; and for his views on progressive rationalization, see Parsons 1977). Finally, Jeffrey Alexander's $(1983,1985)$ criticism of Weber's alleged instrumentalism also has some affinity to Habermas's position. Nevertheless, Habermas differs fundamentally from these other theorists because his interpretation of Weber is part of an effort to revive critical theory.

${ }^{14}$ In his later work, Habermas (1984, pp. 172-74, 285-86) reconstructs Weber's rationality types and elaborates them into "instrumental action," "strategic action," and "communicative action." While the first two action types (subtypes of purposiverational action) have explicit roots in Weber's texts, communicative action reflects Habermas's own idea of normative rationality. This concept varies sharply from Weber's "value-rationality," which does not suggest consensual truth (Weber [1921] 1968, pp. 24-26). Weber thought societal consensus over ultimate values was impossible. Finally, as I will explain below, Habermas intends the concept of communicative action to fill out the unelaborated "broader societal rationality" supposedly implied by Marx, Weber, and critical theory. 
quently, reduced Western rationalization to a march of purposive rationality.

While, on one hand, he claims that Weber's one-sided political sociology equates rationalization with expanding meaninglessness, domination, and regimentation, on the other, Habermas contends that his cultural analysis of disenchantment hints at a more "comprehensive concept of rationality" that provides a counterweight to the value-fracturing and socially coercing features of purposive rationalization (1984, pp. 216-22, 243-54). Therefore, in the search for normative underpinnings, Habermas puts aside Weber's strong emphasis on organizational rationalization and, instead, dwells on his account of religious rationalization. ${ }^{15}$

Habermas's universalistic normative intention comes clearly into view in his critique of Weber's concept of legitimacy (Habermas 1984, pp. 24371; Habermas 1979b, pp. 178-205; Habermas [1973] 1975, pp. 97-110), where he argues that the emphasis on the "belief in legal procedure" is too insubstantial to support rational-legal domination and that it cries out for "moral-practical" justification. He believes that Weber's discussion of legitimacy implies the need for "rationally motivated agreement." The heart of the Habermasian critique is that Weberian legitimacy is purely "empirical" (it stresses exclusively the role of actual beliefs in historical domination systems) and therefore lacks the normative grounds for distinguishing illegitimate from legitimate domination. Here Habermas abandons Weber's sociological and historical approach in an effort to uncover a normative standard of legitimacy. Within his revised critical theory, Habermas fashions this normative conception into a procedural democratic foundation to orient culturally and temporally relative social criticism. But to ground his approach, Habermas must first elaborate the broader societal rationality that was totally occluded by Marxian materialism.

Following Weber, Habermas believes that the West is distinguished by the unique features of its Protestant culture, which produced profound disenchantment and differentiation of the magical and unified worldview of premodern society (Habermas 1984, pp. 186-242). Within the familiar story of Protestant secularization, ${ }^{16}$ Habermas detects seeds of broader societal rationality and democratic legitimacy. Protestantism, in his view,

${ }^{15}$ Habermas (1987c, pp. 153-373) does not ignore purposive rationalization but treats it as a semiautonomous process that runs mostly counter to communicative rationalization and democratization.

${ }^{16}$ Although Habermas (1984, p. 164) acknowledges Weber's balanced concern for material interests and ideal interests, he argues that Weber considered the "methodical conduct of life" to be "a-if not the-most important factor in the rise of capitalism." In his theory of communicative action, Habermas dwells much more on ideal than on material interests. And his reading of Weber reflects this theoretical inclination. 
gave birth to a concept of community constituted of independent moral actors bound by voluntaristic commitment to common ethical norms. This ideal superseded the coercive and nonreflective morality of traditional societies.

By reconstructing Weber's ([1930] 1958a, pp. 13-31) theory of Western cultural rationalization, Habermas establishes evolutionary grounds for his ultimate normative standpoint. Habermas (1984, pp. 176-81) argues that Protestant secularization culminates in three differentiated value spheres (scientific, artistic, ethical), each with its own distinct logic and each governed by a unique "universal validity claim" (truth, beauty/ authenticity, normative rightness). ${ }^{17}$ Most important, he asserts that the differentiation fosters "objective advances" in each sphere. Increased autonomy and rationality (detail, consistency, and clarity) in the ethical sphere heighten the capacity of modern ethical norms for critical reflexiveness and make possible a rational and voluntaristic normative consensus that harmonizes the need for social integration with the preservation of individual moral autonomy. Of course, this ethical integration is the opposite of the blind obedience commanded by Weberian bureaucracies and by traditional societies. The point is that Habermas sees, in Weber's theory of cultural rationalization, an implicit universalistic standard of societal rationality that provides grounds for a concept of democratic legitimacy.

Habermas knows that Weber's conclusions about Western rationalization were not as sunny and that intense value conflict and "pure utilitarianism" stood at the end of his story of capitalist disenchantment (Habermas 1984, pp. 241-42; Weber 1958a, pp. 180-83; Weber [1915] $1958 b$, pp. 355-57). However, Habermas defends his liberal reconstruction by arguing that Weber failed to finish his analysis of Protestantism, leaving the implicit logic of religious rationalization incomplete. In Habermas's view, Weber did not probe closely enough the Protestant "ethic of brotherliness," did not investigate sufficiently social movements (e.g., the Anabaptists) that expressed ethical rationalization in new forms of communality (instead of as capitalist acquisition), ${ }^{18}$ and did not realize the degree to which "moral consciousness" could survive in the secular

${ }^{17}$ Habermas's $(1979 b$, pp. 29,58$)$ earlier discussion of validity claims (truth, rightness, truthfulness) anticipates his later reconstruction of Weber. The question remains whether he derived these concepts from another source and then read them into Weber's work, or the reverse. Most likely, Habermas has been influenced by Kant's division of science, morality, and art (see Rorty 1985, pp. 166-71). Weber's ideas about these matters suggest a much more complex differentiation of value spheres than suggested by Habermas (Lawrence Scaff drew my attention to this point).

18 These matters were taken up by Michael Walzer (1965) in his study of Calvinism and radical politics. Perhaps Habermas was influenced by Walzer's work. 
tradition of Enlightenment rationalism (Habermas 1984, pp. 229-33, 242). Finally, Habermas (1984, pp. 249-54) claims that Weber simply exaggerated the level of value conflict. If Weber had only grasped the significance of value differentiation (i.e., Habermas's three value spheres), he would have realized that the abstract normative standards of modernity operate effectively and provide moral integration for the specialized and differentiated spheres of life. Habermas sees all these problems as deriving ultimately from the fact that Weber, like Marx, tied rationalization too tightly to capitalist development. And this one-sided emphasis on purposive rationality supposedly blinded Weber to the implicit societal rationality contained in his own vision of religious disenchantment (Habermas 1984, pp. 198, 216-22, 233-42; Habermas 1987c, pp. 303-31).

\section{BETWEEN TRANSCENDENTALISM AND HISTORICISM:} HABERMAS'S BROADER SOCIETAL RATIONALITY

His critiques of Marx and Weber set the stage for Habermas's (1979b, pp. 1-68; Habermas 1984, pp. 1-141, 273-337; Habermas 1987c, pp. 1-152) theory of communicative action and standard of communicative rationality. Habermas describes his approach as proceeding "reconstructively, that is, unhistorically," and as "no longer" starting with "concrete ideals immanent in traditional forms of life" (Habermas 1987c, p. 383). Consequently, Habermas abandons the historical immanent critique of Marx and of classical critical theory. Although it contains elements from Marxian and Weberian theory and borrows liberally from American pragmatism, interpretive sociology, linguistic philosophy, linguistics, and developmental psychology, the resulting normative theory is Habermas's own. The core idea is that a universal ideal of uncoerced communication underlies symbolic interaction. Human speech communities are based, ultimately, on an implicit normative content that is ethically rationalized in modernity into a conception of moral autonomy and mutual responsibility (Mündigkeit) (McCarthy 1979, p. xvii). In a nutshell, Habermas argues that competent participants in speech situations must understand the difference between true and false statements and that true statements are those that would be reached if there were unconstrained discussion (Geuss 1981, p. 65). ${ }^{19}$ This "counterfactual" substructure stands in stark

\footnotetext{
19 Habermas (1979b, pp. 1-5, 26-34, 56-59) argues that all successful speech acts raise implicit "validity claims": what is said ought to be comprehensible, true (in "propositional content"), truthful (be a sincere expression of the speaker's intentions), and right (express a recognizable normative content). Social breakdowns or problems in communication cause this background knowledge to be brought to consciousness and into
} 
contrast to the "distorted communication" (based on deception, constraint, and coercion) of actual social interactions and provides a procedural ground for normative critique of the oppressive side of purposive rationalization.

The universalistic normative claims go hand-in-hand with Habermas's evolutionary argumentation about increasing cultural capacities for realizing the potential contained within the "ideal speech situation." Progressive communicative rationalization of societal normative structures favors heightened awareness of the ideal of uncoerced consensus, increased critical sensitivity to distorted communication, and improved social integration based on moral autonomy and mutual responsibility (Habermas 1979b, pp. 69-129; Habermas 1979a; Schmid 1982). Habermas borrows elements from psychologist Lawrence Kohlberg's thought to argue that communicative rationalization is analogous to the process of individual moral development. Moral maturation proceeds from control based on external authority and punishment to self-regulation based on the individual's reflexive selection of moral norms (Habermas 1979b, pp. 78-90). Accordingly, advanced moral development is characterized by highly abstract ethical principles (e.g., justice, reciprocity, equality, and individual dignity) and autonomous moral judgment, permitting morally reflexive responses to the specialized social settings and differentiated life spheres of modernity.

Of course, this portrayal agrees with Habermas's aforementioned reconstruction of Weber's latent conception of broader societal rationality and, particularly, with Habermas's claims about the rationalization of Protestant communality and progressive differentiation of value spheres. Kohlberg's advanced stage of moral development is perfectly consistent with the type of rational and voluntaristic social integration discussed earlier. Habermas (1979b, pp. 105-6, 152-58) hypothesizes that societallevel communicative rationalization follows the same path as the moral maturation of the individual and that progressive normative stages can be demonstrated in the long-term development of Western law and morality (i.e., phylogeny recapitulates ontogeny). The evolution of communicative rationality has proceeded furthest in the West because the unique features of its Protestant heritage have permitted increased cultural expression of universal normative potentialities. ${ }^{20}$

social dialogues (Habermas 1987c, pp. 400-401). For comment on Habermas's complex argument about "communicative competence," see Held (1980, pp. 330-46), McCarthy (1978, pp. 272-357; McCarthy 1979; McCarthy 1984), and Benhabib (1986, pp. 224-353).

${ }^{20}$ Habermas (1979b, pp. 97-98) suggests that normative evolution is conditioned by "economic," "system," and "learning" processes. Also, he gives strong emphasis to counterdevelopments in the sphere of labor, contending that imperialistic purposive 
Despite Habermas's evolutionary normative argumentation, his theory of communicative action does not reproduce the dogmatism of philosophic absolutism or of evolutionary Marxism. First, the approach breaks with the absolutist "philosophy of consciousness" by locating the ultimate sources of normative validity in the social world rather than in the a priori characteristics of an intuited transcendental subject. Second, Habermas supplants evolutionary Marxism's ("philosophy of the subject") uncritical conception of a collective emancipatory subject with an approach that emphasizes the conditions for reaching intersubjective agreements about emancipatory goals (Habermas 1983, pp. 53-127; Habermas 1987a; Benhabib 1985; Wolin 1987). In this way, Habermas defines as problematic the process of communication that Marx left undeveloped and opens to dialogue the substantive normative content that official Marxists put beyond criticism. Habermas reconstructs the ideal of rational society into a social order where people resolve contested issues consensually by observing procedural norms of democratic discourse, resulting in communicatively rational, voluntaristic social integration. This approach avoids the main trap that ruined his Enlightenment predecessors and their more recent technocratic offspring; Habermasian democracy does not flow unproblematically from the stream of material and technical progress but must be achieved "communicatively."

Still Habermas's moral universalism and evolutionary argumentation contain taints of the very positions he wants to leave behind. But he claims to make a clean break from these earlier a priori normative theories (Habermas 1987a, pp. 294-326; Habermas 1987b, pp. 310-11; Habermas 1985d, pp. 195-98; Habermas 1984, p. 138; Habermas 1987c, pp. 396-403; Habermas 1979b, pp. 21-25). Against those who would accuse him of transcendentalism (e.g., Geuss 1981, pp. 64-70), Habermas argues that communicative rationality expresses "unproblematic background convictions" of speech acts, and, therefore, his universal normative standard is immanent in everyday social interaction (Habermas 1984, pp. 70, 342-43; Habermas 1987c, pp. 113-52). This completes Habermas's highly complex maneuver. His embrace of modernity rules out a return to moral absolutism, while his critical approach to bourgeois values demands that he also reject historicism. Instead, he contends that

rationalization, in the modern form of the "functionalist reason of system maintenance," expands fiscal and bureaucratic imperatives and undermines voluntaristic social integration and democratic legitimacy. Habermas's discussions of "system integration" vs. "social integration," "system" and "lifeworld," "colonization of the lifeworld," and "new social movements" are relevant here but cannot be discussed in this paper (see Habermas 1975 , pp. 1-31; Habermas 1984, pp. 70-71, 335-37, 39799; Habermas 1981b; Habermas 1987c; Wellmer 1985a, pp. 51-57). 
investigations of the taken-for-granted substructure of human communication yield universal procedural grounds for democratic legitimacy and that progressive rationalization unlocks more determinate potentialities of this underlying normative content. The shape of Habermas's normative foundation reflects his effort to steer a course between transcendentalism and historicism.

\section{IS IT EMANCIPATORY THEORY? ETHICAL FORMALISM AND THE SOCIOLOGICAL DEFICIT OF HABERMASIAN THEORY}

Hard-line critics dismiss the theory of communicative action for being too thin historically, too moderate politically, and too rationalistic analytically to qualify as emancipatory theory. ${ }^{21}$ Yet even Habermas's friendly interpreters contend that his theory cannot express the rich forms of intersubjectivity (i.e., modes of sympathy and collective identification) inherent in the social bonds that integrate communities and social movements (e.g., Benhabib 1986, pp. 327-53). For this reason, they question the theory's capacity "to command the allegiance of its potential addressees" (Wolin 1987, p. 52). If dialectical materialism is analogous to Calvinist fundamentalism, then the theory of communicative action can be compared to Kantian ethical formalism. Because his universalistic normative stance applies to all modern social contexts, it has little substantive to say about any single context. Therefore, Habermas restores emancipatory theory formalistically, forsaking the bold historical claims about unmet needs and about specific possibilities for change that enlivened Marx's historical immanent critique. And this problem of formalism arises from the sociological deficit that accompanies Habermas's effort to derive a semiautonomous evolutionary logic of normative rationalization.

Marx linked emancipatory values inextricably to conjunctural forms of socioeconomic organization and to accompanying patterns of association, cooperation, and needs. Likewise, Weber stressed the same type of historical interplay between normative structures and organizational conditions. Habermas exaggerates the degree to which Marx's and Weber's organizational analyses expressed a triumphant march of purposive rationality. Though they treated rationalization as a single historical process shaped centrally by capitalist development, the two classical theo-

${ }^{21}$ They argue that Habermas's "minimalist" critique is nothing more than a philosophical justification for liberal reformism. This issue has been the focus of a divisive polemical debate within critical theory (e.g., Honneth 1979; Schmidt 1979; Feher 1985; Whitebook 1985, 1986; Breines 1985; Wolin 1985; Gonzales 1985, 1986; Corradi and Piccone 1985-86). 
rists recognized multiple and varied threads of material and ideal interests in complex and sometimes contradictory relationships. The unintended consequences of the resulting patterns of development produced possibilities for increased democracy as well as for intensified domination and coercion. Most important, by not separating normative rationalization from organizational rationalization, Marx and Weber kept their approaches close to the historical process and avoided lapsing into the type of speculation that bankrupted the ideas of their more idealistically inclined contemporaries.

Though Habermas acknowledges interdependence and interchange between the functional domain of societal organization and the normative realm of communicative action, his conceptualization of these two spheres as boundary-maintaining systems with fundamentally opposed developmental logics and, most important, his purely cultural analysis of communicative rationalization constitute a sharp break with the dialectical, historical analysis of organization and values that characterized the sociologies of Marx and Weber. Consequently, though he formally recognizes their importance, political economy and complex organization together become largely an abstract systemic backdrop for Habermas's normative theory. Yet these spheres of life are where many of the most pressing normative issues of modernity have meaning for people. Habermas's democratic ideal is disembodied from the determinate types of substantive sociological and historical content that animated early emancipatory theory and, thus, continues the philosophical drift of later critical theory. The theory of communicative action does not discourage the unfortunate tendency of many critical theorists to compensate for the onesided materialism of orthodox Marxism with an equally one-sided cultural critique that ignores political economy and organizational analysis.

But, despite the strengths of the sociologies of Marx and Weber, Habermas's critique of their thinly developed ideas about democracy is mostly on target. And they do not contain the key to elaborating the deeper forms of intersubjectivity missing from Habermas's approach. Contemporary normative debates about democracy and emancipation cannot be resolved by returning to Marx, Weber, or critical theory (see Cohen 1985). On the other hand, Habermas's formalistic normative argument does not resolve the old problems but does introduce new ones.

\section{CRITICAL THEORY DOWN TO EARTH: PRAGMATISM AND EMANCIPATORY THEORY}

The weaknesses and potentialities of Habermasian theory should be assessed from the vantage point of its ambivalent relationship to American pragmatism. Although he embraces the pragmatist themes of radical 
democracy and intersubjectivity, Habermas's emphases on ethical universalism and evolutionary normative justification contradict the approaches of George H. Mead and John Dewey. In a telling statement, Habermas (1985d, p. 197) implies that the pragmatists sought to replace the defunct form of religiously based social integration with "the unifying, consensus-creating power of reason." While taints of this view surely exist in the pragmatist tradition (particularly in the thought of Royce and Pierce), Mead and Dewey provide the basis of a radically secular approach that breaks fundamentally from the conception of normative consensus that underlies the civil religion of Durkheim or Parsons as well as the milder procedural universalism of Habermas. ${ }^{22}$

Seyla Benhabib (1986, pp. 341-43) concludes her penetrating study of the foundations of critical theory with sympathetic criticism of Habermas that resonates with the pragmatist critique of ethical formalism. But Benhabib suggests that Habermas inherited his rationalistic, quasiKantian universalism from Mead. She implies that Mead's universal communication community, ${ }^{23}$ which supposedly underlies Habermas's conception of democratic legitimacy, pivots on an overly rational concep-

${ }^{22}$ Habermas views Mead as a path-breaking thinker who recognized implicity the significance of communicative rationality but failed to express it fully and rigorously in theory (see Habermas 1987c, pp. 1-111; Ingram 1987, pp. 104-14; and for a brief summary of Mead's ethical theory, see Joas [1980] 1985, pp. 121-44). Though Mead stepped away from "the philosophy of consciousness" (by stressing intersubjectivity and communication), he supposedly did not give sufficient consideration to normatively regulated action and to consensual communication and, thus, never completed the trek up the heights to communicative rationality. Habermas (1987c, pp. 14-15, 22-25) contends that Mead did not take into account the alleged capacity of different interactants to ascribe "identical meaning" to a single gesture and overlooked the type of communicative action that culminates in "rationally motivated agreement." Still he claims (1987c, pp. 94-95) that Mead presumes communicative rationality in his central concept of the "ideal communication community." Habermas (1987c, pp. 44-45) wants to plug the conceptual gap in Meadian theory by incorporating Durkheimian conceptions of collective consciousness and normative consensus. As in the "reconstruction" of Weber, Mead is read as if he were on the brink of Habermas's project and in the broader tradition of Durkheim and Parsons, which envisions the fate of modernity as hinging on the continued emergence of a normative consensus around highly generalized, secularized, and rationalized Protestant values (see Vidich and Lyman 1985). This civil religion problematic is a theoretical cul-de-sac that yields evolutionary normative justification and ethical formalism. Conversely, the conception of radical democracy in the work of Mead and Dewey dispenses with civil religion and, for that reason, provides a more promising basis for appropriating the emancipatory elements of the Marxian and Weberian traditions.

${ }^{23}$ Though universals and universalism were sometimes mentioned in Mead's discussions of normative matters, they referred to ideals that emerged from historically bounded universes of discourse. See n. 2 and Mead ([1934] 1967, pp. 82-90, 253-336). (Harold L. Orbach drew my attention to this point and has been extremely helpful in this entire section on pragmatism.) 
tion of the "generalized other" too narrowly conceived to take account of the broader experiences of sympathetic understanding and mutual identification that bind people to communities and command their allegiance to social movements.

Though her criticism of Habermas is well aimed, the weaknesses she identifies do not originate in Mead's thought. To be properly understood, the "generalized other" must be put in the context of what Mead called "sharing the attitudes of the other" (role taking) and the rich intersubjectivity it entails. The sharing of attitudes is not restricted to rational criteria but includes the capacity for sympathetic identification with other persons' needs, sufferings, and feelings. Contrary to Benhabib's view, Mead did not devalue the types of experiences that she associates with communality and detects rightly as being absent from Habermasian formalism. ${ }^{24}$ The narrow vision of intersubjectivity follows, instead, from Habermas's effort to steer between transcendentalism and historicism. On the contrary, Mead's robust intersubjectivity goes hand-in-hand with pragmatist historicism and the full acceptance of the secular nature of modernity.

By establishing intersubjective processes as the ultimate standards of normative validity, Habermas appears to integrate critical theory with pragmatism. Yet the fusion is partial and contradictory because he weds intersubjective normative standards uncomfortably to quasi-foundationalist universalism. The line of reasoning behind this approach can be detected in Habermas's (1973, p. 272; Habermas 1970, pp. 66-80) early writings, where he acknowledged an affinity between his own critique of technocracy and that of John Dewey but argued that Deweyan pragmatism, applied today, overlooks "the structural change in the bourgeois public realm" and, consequently, appeals to uncritical norms that affirm technocracy (Habermas 1970, p. 69). ${ }^{25}$ From the start, Habermas could accept only selected pieces of pragmatism, which he would later weave

\footnotetext{
${ }^{24}$ Benhabib does not deal directly with Mead's texts, and her comments about the "generalized other" seem to be based entirely on Habermas's reading of Mead and, particularly, on a short passage that Habermas quoted from Mead (Benhabib 1986, pp. 339-40; Habermas 1987c, pp. 94-95; Mead [1930] 1964, pp. 404-5). In a more recent essay Benhabib (1987, p. 78, n. 23) backs off from her criticism of Mead and states that the rationalistic concept of "generalized other" she criticizes does not belong to Mead. For the discussion of "sharing of attitudes," "generalized other," and "communication community," see Mead (1967, pp. 253-336).

${ }^{25}$ Horkheimer (1974, pp. 41-57), in a primary text of the "dialectic of Enlightenment," argued that Deweyan pragmatism justifies the prevailing one-dimensionality of technocracy. While Habermas is much more sympathetic to Dewey, taints of the older generation's critique remain. And this follows from his partial appropriation of their cultural pessimism.
} 
into a universalistic normative theory that contradicts central tenets of the pragmatist approach to values.

Dewey contended that ethical universalism generates a legalistic attitude that robs morality of its spontaneity and relevance for life (Dewey and Tufts 1985, pp. 275-83), degrades practical activity (Dewey [1929] $1984 d$, p. 58), and sets "up ends without means for their realization" (Dewey and Tufts 1985, p. 344). And evolutionary normative arguments do not escape the problems of the older forms of absolutism (Dewey [1927] $1984 c$, pp. 357-58). According to the pragmatists, all normative content, even that which is supposed to be true in all places and for all times, arises from specific cultural and historical contexts. In Dewey's view, universalistic claims are usually intended to drape historical institutions with a legitimacy that is impervious to critical dialogue (Dewey 1984d, p. 211) or to impose the goals of political leaderships and planning elites (Dewey 1984c, pp. 360-61). But even when they are not a cover for an elitist agenda, universalistic claims diminish normative dialogue about social issues. Arthur Edward Murphy (1965, pp. 329-30) expressed this antiformalist position eloquently:

We must have grounds more relative than this. The notion that concrete issues of better and worse, right and wrong, can be settled by a "rational" reference to good in general, from the point of view of the universe, which our own "reason" somehow "dictates" that we follow is at once pretentious and equivocal. Our reasons are not, and should not be, of this morally rootless and disembodied sort. They are the considerations we learned to understand and honor as obligations in the family, the community, the nation into which we were born, and in whose shared life we have become such moral agents as we are. And these are not universal communities; they have a local habitation and name. . . . And in this work, what is too good for this world is, for practical and moral purposes, not good enough. It is, as we have now amply seen, an evasion, not an effective answer, to our actual problems.

Dewey was not naive about bourgeois ideals. He argued that the national community they once reflected had already passed away (1984c, pp. 304-24) and that these ideals now justify technocratic planning and elite decision making (1984c, p. 329). Yet he also believed that more determinate forms of democratic values existing at the face-to-face level of everyday associations in families and neighborhoods still provided immanent valuative grounds for democratic critique (1984c, pp. 325-50, 367-72). The heritage of democracy, in his view, is reappropriated daily at the local level, where it is refashioned in cooperative activities, dealing with contemporary situations and experiences of need and expressing still-existing communal bonds. But these normative understandings are often unspoken and tend to be excluded entirely from national-level dialogue. 
Pragmatist public philosophy counters mass-media propaganda and political demagoguery with symbols and moral rhetoric that give voice to these living moral bonds and take them beyond the boundaries of local communities. Like Marx's historical immanent critique, Dewey's "experimental method" calls for testing the normative claims of public values against the historical realities that they supposedly depict and for revising them in response to existing communal understandings and existing unmet needs (1984c, pp. 361-62). Of course the pragmatists understood that restoring a democratic public at the national level was a formidable task. That their efforts yielded no shining path to democracy reflected both the strengths and limits of a method that was intended to express the possibilities of the day.

Clearly, the communication community implied by Dewey bears little resemblance to the narrow rationalism decried by the critics of Habermas and mistakenly attributed to Mead. Dewey argued that moral bonds emerge from experiences of cooperative activities, common needs, and shared history and that these bonds are sustained "emotionally" and intellectually (1984c, p. 330). Dewey ([1926] 1984a, [1926] 1984b) and the pragmatists rejected the tendency of Western religious and philosophical thought to oppose moral experience to sensuous life and, instead, considered morality to contain affective, aesthetic, and material as well as rational threads. Dewey's (1984c, pp. 367, 371) "free and full intercommunication" referred to the rich intersubjectivity essential to the maintenance of community and to the vitality of social movements.

The pragmatist themes of communication, community, and democracy provide the type of corrective to Marxism called for by Habermas and other critics of Marxist economism. In particular, Dewey demolished the central economistic dogma (of the Right as well as the Left) that "social interdependency" and "harmony" would someday flow automatically from advances in production and exchange (e.g., 1984c, pp. 332-33; Dewey 1935, pp. 6-11,35). On the other hand, Dewey's approach still has affinity for Marx's historical immanent critique. And similar to Marx's, Dewey's normative theory is framed within a critique of subjective idealism, emphasizing the unity of theory and practice $(1984 \mathrm{c}$, p. 224). Most important, Dewey argued that economic issues ought to be at the center of moral dialogue because the achievement of the good life depends on the maintenance of its material underpinnings. He argued that economic standing determines the scope of one's participation in the cultural life of modernity (1984d, pp. 224-25) and that class domination was a characteristic feature of the new technocracy (1984c, p. 362). Since Dewey treated the organizational and normative dimensions interactively, the critique of economism did not diminish the sociological powers of his approach, nor did it justify one-sided cultural critique. 
But pragmatism is no cure-all. It does not contain a secret remedy for democratizing mass society, nor does it promise to solve all the varied and complex problems that have long plagued emancipatory theory. Finally, it is not a substitute for critical theory. ${ }^{26}$ Instead, my point has been merely to make a case for completing the secular and intersubjective turn in critical theory begun by Habermas and to encourage a broader dialogue with pragmatism. ${ }^{27}$ Such an encounter between the two traditions would force emancipatory theory, finally, to come to terms with the historical claims upon which it was founded. The problem of formalism can be overcome, and the true limits of immanent critique clarified, only after all the pseudohistorical baggage is left behind. For those who are passionately committed to emancipatory values, facing the historical process without illusions is a risky proposition. Yet only a fundamental reconstruction of the approach on this purely temporal plane can bring emancipatory theory down to earth and, possibly, back to the center of public consciousness and discussion.

The demise of the orthodox Left has nearly put an end to reified hopes about the march of a historical metalogic and the progressive emergence of a collective emancipatory subject, but new foundationalist tunes are being played outside official Marxist circles. The problems of transhistorical normative justification and ethical formalism extend far beyond the borders of emancipatory theory. Because of the multiple crises of the past 20 years (e.g., the decline in public-spiritedness, the full bloom of the culture of narcissism and possessive individualism, the ineffectiveness of the "overloaded state," and multiple disruptions from international economic restructuring and deindustrialization), many social and political theorists now warn about the precarious condition. of the cultural and economic substructure of liberal democracy. Normative approaches ranging from the Straussian and neoconservative Right to the social democratic and critical Left (e.g., Bell 1976; Bellah et al. 1986; Bloom 1987; Bowles and Gintis 1986; Eden 1983; Gewirth 1978; Ignatieff 1986; Nozick 1974; Phillips 1986; Rawls 1971; Sullivan 1982; Vidich and Lyman 1985) have raised repeatedly the need to shore up the normative underpinnings of Western democracy to avert a slide into despotism.

${ }^{26}$ Since they were reformists, the pragmatists did not build a strong utopian dimension into their theories. The vision of radically different modes of consciousness and radically transformed modes of social being have been a primary feature of the emancipatory tradition and essential to its goal of appealing to people to alter the course of history (Douglas Kellner reminded me of this point).

${ }^{27}$ Richard Rorty (e.g., 1979, 1982, 1985, 1987) calls for a closer relationship between pragmatism and social critique and has criticized Habermas's quasi foundationalism on this account. See Habermas's $(1987 b)$ response to Rorty and also Rick Roderick's (1986, pp. 8-13) critique of the antifoundationalist position. 
Lurking beneath these normative defenses is the image of a dystopian regime far more oppressive than the depoliticized managerial order feared by critics of commercial society from Tocqueville to Marcuse. Habermas's so-called minimalism or joyless reformism must be put in the context of these apparent threats to the civilizing features of bourgeois society (e.g., rule of law, citizenship rights). ${ }^{28}$ But, if liberal institutions are really in trouble, ethical universalism, even in the conditioned and undogmatic form of Habermasian theory, can do little to help.

The new foundationalism has not gone unchallenged. At the other extreme, "postmodernists" ${ }^{29}$ preach an antimoralist line, claiming to defend cultural diversity against imperialistic moral rationalism. Between the lines of their difficult "genealogical" and "deconstructionist" jabs at ethical holism is the recycled pessimism of the "dialectic of Enlightenment." But the earlier round of this antirationalist broadside was fired during the euphoric expansion of consumer society, when, despite Joseph McCarthy, citizenship rights were expanding, and the underpinnings of liberal democracy seemed secure. Pessimistic critical theorists tried to supply brakes for overweening postindustrial optimism. However, today, can the postmodernist condemnation of the mildest emancipatory arguments (e.g., Habermas's defense of democracy) as repressive "grand narratives" be considered a corrective? Radical postmodernism leaves no space for broader moral rhetorics that address the problem of declining

${ }^{28}$ Habermas (1981a, p. 15; Habermas $1981 c$, pp. 8-9, 13-14; see also Jay 1984b, pp. 6-7) states that the "real motive" of his recent work is to preserve "the project of modernity." He opposes the onslaught of postmodernists who accept moral diversity but reject global defenses of democracy (see Lyotard [1979] 1984) as well as that of neoconservatives who call for a return to traditional values and obedience to authority (see Bell 1976). This theoretical debate over modernity has been waged in an era of conservative assault on the welfare state, cultural warfare by the far Right and fundamentalist religious groups, and exhaustion of the Left. Habermas construes his normative theory as an affirmation of Enlightenment rationalism and democratic political institutions in the face of a rising wave of irrationalism, traditionalism, and authoritarianism. See Habermas (1981c, 1982, 1985a, 1985c, 1987a), Giddens (1981), Benhabib (1981), Foster (1984), Bernstein (1985), Wellmer (1985b), Hohendahl (1985, 1986), and Jay (1984b). Habermas's sympathetic critics further elaborate his basic concern about the fate of democracy (e.g., see Thompson and Held 1982; Cohen 1982; Keane 1984; McCarthy 1985; Misgeld 1985; Giddens 1985; Fraser 1985; Halfmann 1985; Ferrara 1985; Rorty 1985; Benhabib 1981, 1985, 1986; Sciulli 1985, 1986; Wolin 1987).

29 Postmodernism is a vague conception that includes a broad range of positions and overlaps poststructuralism. My own argument has postmodernist features since it is historicist and pluralist. My critical comments are aimed at the more radical versions that reduce the world to discourse and that forbid global moral rhetorics. See Berman (1982), Baudrillard (1983), Lyotard (1984), Wolin (1984/1985), Kroker (1985), Callinicos (1985), Kroker and Cook (1986), Dews (1987), and Kellner (1988). 
national community. It is silent about societal-level strategies for dealing with mounting unmet needs, the retreat from welfarism, or the downward compression of the middle class and, consequently, fails to confront the threat of despotism.

By conditionally affirming modernism and preserving the emancipatory ideal of the Enlightenment in the much scaled-down form of a "reasonable society," pragmatism provides an alternative to foundationalist formalism and to postmodernist cynicism. Most important, pragmatist moral rhetoric provides a starting point for an approach that breaks fundamentally with the repressed Protestantism and stale moralism still latent within much sociological theory and sublimated in ideals of normative agreement. Pragmatist social integration depends on the capacity to share attitudes and does not rely on value consensus; sympathetic understanding of the other does not require agreement or homogeneity. Indeed, the pragmatists' guarded optimism about modernity was based on their belief that the flexible role-playing required by specialized organizational structures and differentiated spheres of life would increase the capacity to share attitudes and, at the same time, increase tolerance of diversity. Under these conditions, disputes can be resolved by compromise and trade-offs grounded in mutual understanding and compassionate understanding of difference. The pragmatist communicative ideal does not implicitly call for the re-creation of an idealized village culture at the societal level and, therefore, veers away from the utopian visions of consensual national communities that sometimes provide justification for totalitarian "moral" orders.

Fundamentalist forms of moralism, which seem to abound nowadays, directly undermine efforts to confront the burning issues of the day soberly and openly. A broader cultural revival of pragmatist realism surely would provide a good sociological antidote to this absolutist current and a democratic counterpunch to the despotic shadow that may follow the next serious recession. And emancipatory theorists have the opportunity to initiate this critical dialogue.

\section{REFERENCES}

Adorno, Theodor W. [1966] 1973. Negative Dialectics, translated by E. B. Ashton. New York: Seabury.

Alexander, Jeffrey C. 1983. The Classical Attempt at Synthesis: Max Weber. Theoretical Logic in Sociology, vol. 3. Berkeley and Los Angeles: University of California Press.

. 1985. "Review Essay: Habermas's New Critical Theory: Its Promise and Problems." American Journal of Sociology 91:400-424.

Antonio, Robert J. 1981. "Immanent Critique as the Core of Critical Theory: Its 
Origins and Developments in Hegel, Marx, and Contemporary Thought." British Journal of Sociology 32:330-45.

- 1983. "The Origin, Development, and Contemporary Status of Critical Theory." Sociological Quarterly 24:325-51.

. 1987. "Reason and History in Hayek." Critical Review 2:58-73.

Baudrillard, Jean. 1983. Simulations. New York: Semiotext(e).

Bell, Daniel. 1976. The Cultural Contradictions of Capitalism. New York: Basic.

Bellah, Robert N., Richard Madsen, William M. Sullivan, et al. 1986. Habits of the Heart. New York: Harper \& Row.

Benhabib, Seyla. 1981. "Modernity and the Aporias of Critical Theory." Telos 49:3959.

. 1985. "The Utopian Dimension in Communicative Ethics." New German Critique 35:83-96.

- 1986. Critique, Norm, and Utopia. New York: Columbia University Press. - 1987. "The Generalized and the Concrete Other: The Kohlberg-Gilligan Controversy and Feminist Theory." Pp. 77-95 in Feminism as Critique: On the Politics of Gender, ed. by Seyla Benhabib. Minneapolis: University of Minnesota Press.

Berman, Marshall. 1982. All That Is Solid Melts into Air. New York: Simon \& Schuster.

Bernstein, Richard J., ed. 1985. Habermas and Modernity. Cambridge: MIT Press.

Bloom, Allan. 1987. The Closing of the American Mind. New York: Simon \& Schuster.

Bowles, Samuel, and Herbert Gintis. 1986. Democracy and Capitalism. New York: Basic.

Breines, Paul. 1985. "Redeeming Redemption." Telos 65:152-58.

Callinicos, Alex. 1985. "Postmodernism, Post-Structuralism, Post Marxism?" Theory, Culture and Society 2:85-101.

Cohen, G. A. 1978. Karl Marx's Theory of History. Princeton: Princeton University Press.

Cohen, Ira J. 1985. "The Underemphasis on Democracy in Marx and Weber." Pp. 274-99 in A Weber-Marx Dialogue, edited by Robert J. Antonio and Ronald M. Glassman. Lawrence: University Press of Kansas.

Cohen, Jean L. 1982. Class and Civil Society: The Limits of Marxian Critical Theory. Amherst: University of Massachusetts Press.

Corradi, Juan, and Paul Piccone. 1985-86. "Introduction." Telos 66:3-5.

Dewey, John. 1935. Liberalism and Social Action. New York: Putnam. . [1926] 1984a. "Affective Thought." Pp. 104-10 in John Dewey: The Later Works, 1925-1953, vol. 2. Edited by Jo Ann Boydston. Carbondale: Southern Illinois University Press.

-. [1926] 1984b. "Art in Education-and Education in Art." Pp. 111-15 in John Dewey: The Later Works, 1925-1953, vol. 2. Edited by Jo Ann Boydston. Carbondale: Southern Illinois University Press.

- [1927] 1984c. The Public and Its Problems. Pp. 238-372 in John Dewey: The Later Works, 1925-1953, vol. 2. Edited by Jo Ann Boydston. Carbondale: Southern Illinois University Press.

- [1929] 1984d. The Quest for Certainty. Pp. 3-250 in John Dewey: The Later Works, 1925-1953, vol. 4. Edited by Jo Ann Boydston. Carbondale: Southern Illinois University Press.

- [1925] 1984e. "Value, Objective Reference and Criticism." Pp. 78-97 in John Dewey: The Later Works, 1925-1953, vol. 2. Edited by Jo Ann Boydston. Carbondale: Southern Illinois University Press.

Dewey, John, and James Hayden Tufts. [1932] 1985. Ethics. Pp. 3-462 in John Dewey: The Later Works, 1925-1953, vol. 7. Edited by Jo Ann Boydston. Carbondale: Southern Illinois University Press. 
Dews, Peter. 1986. Logics of Disintegration. London: Verso.

Dubiel, Helmut. [1978] 1985. Theory and Politics, translated by Benjamin Gregg. Cambridge: MIT Press.

Durkheim, Emile. [1893] 1964. The Division of Labor in Society, translated by George Simpson. New York: Free Press.

Eden, Robert. 1983. Political Leadership and Nihilism. Tampa: University Presses of Florida.

Feher, Ferenc. 1985. "Redemptive and Democratic Paradigms in Radical Politics." Telos 63:147-56.

Ferrara, Allesandro. 1985. "A Critique of Habermas' Diskursetik." Telos 64:45-74.

Foster, Hal. 1984. "(Post)Modern Polemics." New German Critique 33:67-78.

Fraser, Nancy. 1985. "What's Critical about Critical Theory? The Case of Habermas and Gender." New German Critique 35:97-131.

Geuss, Raymond. 1981. The Idea of a Critical Theory. New York: Cambridge University Press.

Gewirth, Alan. 1978. Reason and Morality. Chicago: University of Chicago Press.

Giddens, Anthony. 1981. "Modernism and Postmodernism." New German Critique 22:15-18.

- 1982. "Labour and Interaction." Pp. 149-61 in Habermas: Critical Debates, edited by John B. Thompson and David Held. Cambridge: MIT Press.

- 1985. "Reason without Revolution? Habermas's Theorie des kommunikativen Handelns." Pp. 95-121 in Habermas and Modernity, edited by Richard J. Bernstein. Cambridge: MIT Press.

Gonzales, Moishe. 1985. "Theoretical Amnesia." Telos 65:163-70.

- 1986. "Against the Post-Marxist Pseudo-Left." Telos 69:157-61.

Gouldner, Alvin W. 1980. The Two Marxisms. New York: Oxford University Press. Gray, John. 1984. Hayek on Liberty. New York: Basil Blackwell.

Habermas, Jürgen. 1962. Strukturwandel der Offentlichkeit. Neuwied: Luchterhand. Beacon.

- [1968] 1970. Toward a Rational Society, translated by Jeremy J. Shapiro. Boston: Beacon.

[1968] 1971. Knowledge and Human Interests, translated by Jeremy J. Shapiro. Boston: Beacon.

. [1964] 1974. "The Public Sphere: An Encyclopedia Article (1964)." New German Critique 3:49-55.

. [1973] 1975. Legitimation Crisis, translated by Thomas McCarthy. Boston: Beacon.

. [1976] 1979a. "History and Evolution." Telos 39:5-44.

. [1976] 1979b. Communication and the Evolution of Society, translated by Thomas McCarthy. Boston: Beacon.

- 1981a. "The Dialectics of Rationalization: An Interview with Jürgen Habermas," interviewed by Axel Honneth, Eberhard Knödler-Bunte, and Arno Widmann. Telos 49:5-31.

. 1981b. "New Social Movements." Telos 49:33-37.

. 1981c. "Modernity versus Postmodernity." New German Critique 22:3-8. 1982. "The Entwinement of Myth and Enlightenment: Re-Reading Dialectic of Enlightenment." New German Critique 26:13-30.

- 1983. Moralbewusstsein und kommunikatives Handeln. Frankfurt: Suhrkamp.

. [1981] 1984. The Theory of Communicative Action, vol. 1. Translated by Thomas McCarthy. Boston: Beacon.

105 
1985b. "Aspects of the Rationality of Action." Pp. 185-205 in Rationality Today, edited by Theodore Geraets. Ottawa: University of Ottawa Press.

- 1985c. "Neoconservative Culture Criticism in the United States and West Germany: An Intellectual Movement in Two Political Cultures." Pp. 7894 in Habermas and Modernity, edited by Richard J. Bernstein. Cambridge: MIT Press.

- 1985d. "Questions and Counterquestions." Pp. 192-216 in Habermas and Modernity, edited by Richard J. Bernstein. Cambridge: MIT Press.

Press.

[1985] 1987a. The Philosophical Discourse of Modernity. Cambridge: MIT

. 1987b. "Philosophy as Stand-In and Interpreter." Pp. 296-315 in After Philosophy, edited by Kenneth Baynes, James Bohman, and Thomas McCarthy. Cambridge: MIT Press.

- [1981] 1987c. The Theory of Communicative Action, vol. 2. Translated by Thomas McCarthy. Boston: Beacon.

Halfmann, Jost. 1985. "The German Left and Democracy," review of Observations on 'The Spiritual Situation of the Age,' edited by Jürgen Habermas. New German Critique 35:165-86.

Hayek, F. A. 1983. Knowledge, Evolution, and Society. London: Adam Smith.

Held, David. 1980. Introduction to Critical Theory. Berkeley and Los Angeles: University of California Press.

Hohendahl, Peter Uwe. 1974. "Jürgen Habermas: The Public Sphere (1964)." New German Critique 3:45-48.

. 1979. "Critical Theory, Public Sphere and Culture: Jürgen Habermas and His Critics." New German Critique 16:89-118.

- 1985. "The Dialectic of Enlightenment Revisited: Habermas' Critique of the Frankfurt School." New German Critique 35:3-26.

. 1986. "Habermas' Philosophical Discourse of Modernity." Telos 69:49-65.

Honneth, Axel. 1979. "Communication and Reconciliation: Habermas' Critique of Adorno." Telos 39:45-61.

Horkheimer, Max. [1947] 1974. Eclipse of Reason. New York: Seabury.

Horkheimer, Max, and Theodor W. Adorno. [1944] 1969. Dialectic of Enlightenment, translated by John Cumming. New York: Seabury.

Ignatieff, Michael. 1986. The Needs of Strangers. New York: Penguin.

Ingram, David. 1987. Habermas and the Dialectic of Reason. New Haven: Yale University Press.

Jay, Martin. 1973. The Dialectical Imagination. Boston: Little, Brown.

1984a. Marxism and Totality. Berkeley and Los Angeles: University of California Press.

. 1984b. "Habermas and Modernism." Praxis International 4:1-14.

Joas, Hans. [1980] 1985. G. H. Mead. Cambridge: MIT Press.

Kalberg, Stephen. 1979. "The Search for Thematic Orientations in a Fragmented Oeuvre: The Discussion of Max Weber in Recent German Sociological Literature." Sociology 13:127-39.

Keane, John. 1984. Public Life and Late Capitalism. New York: Cambridge University Press.

Kellner, Douglas. 1985. "Critical Theory, Max Weber, and the Dialectics of Domination." Pp. 89-116 in A Weber-Marx Dialogue, edited by Robert J. Antonio and Ronald M. Glassman. Lawrence: University Press of Kansas.

- 1988. "Postmodernism as Social Theory: Some Challenges and Problems." Theory, Culture and Society 5:239-69.

Kroker, Arthur. 1985. "Baudrillard's Marx." Theory, Culture and Society 2:69-83.

Kroker, Arthur, and David Cook. 1986. The Postmodern Scene. New York: St. Martin's. 
Lyotard, Jean-Francois. [1979] 1984. The Postmodern Condition: A Report on Knowledge, translated by Geoff Bennington and Brian Massumi. Minneapolis: University of Minnesota Press.

McCarthy, Thomas. 1978. The Critical Theory of Jürgen Habermas. Cambridge: MIT Press.

. 1979. "Translator's Introduction." Pp. vii-xxiv in Communication and the Evolution of Society, by Jürgen Habermas. Translated by Thomas McCarthy. Boston: Beacon.

- 1984. "Translator's Introduction." Pp. v-xxxvii in The Theory of Communicative Action: Reason and the Rationalization of Society, vol. 1. By Jürgen Habermas. Translated by Thomas McCarthy. Boston: Beacon.

- 1985. "Complexity and Democracy, or the Seducements of Systems Theory." New German Critique 35:27-53.

McMurtry, John. 1978. The Structure of Marx's World-View. Princeton: Princeton University Press.

Marcuse, Herbert. 1964. One-Dimensional Man. Boston: Beacon.

Marx, Karl. [1859] 1970. A Contribution to the Critique of Political Economy. Moscow: Progress.

Marx, Karl, and Frederick Engels. [1845-46] 1964. The German Ideology. Moscow: Progress.

Mead, George H. [1930] 1964. "Philanthropy from the Point of View of Ethics." Pp. 392-407 in Selected Writings (of Mead), edited by Andrew J. Reck. New York: Liberal Arts.

- [1934] 1967. Mind, Self, and Society. Chicago: University of Chicago Press.

Misgeld, Dieter. 1985. "Critical Hermeneutics versus Neoparsonianism." New German Critique 35:55-82.

Murphy, Arthur Edward. 1965. The Theory of Practical Reason. La Salle, Ill.: Open Court.

Nozick, Robert. 1974. Anarchy, State, and Utopia. New York: Basic.

Parsons, Talcott. 1949. Essays in Sociological Theory: Pure and Applied. Glencoe, IIl.: Free Press.

. 1960. Structure and Process in Modern Societies. Glencoe, Ill.: Free Press.

. [1947] 1964. "Introduction." Pp. 3-86 in The Theory of Social and Economic Organization, by Max Weber. Translated by A. M. Henderson and Talcott Parsons. Edited by Talcott Parsons. New York: Free Press.

- [1937] 1968. The Structure of Social Action, vol. 2. New York: Free Press. tice-Hall.

Phillips, Derek L. 1986. Toward a Just Social Order. Princeton: Princeton University Press.

Rader, Melvin. 1979. Marx's Interpretation of History. New York: Oxford University Press.

Rawls, John. 1971. A Theory of Justice. Cambridge: Harvard University Press.

Roderick, Rick. 1986. Habermas and the Foundations of Critical Theory. New York: St. Martin's.

Rorty, Richard. 1979. Philosophy and the Mirror of Nature. Princeton: Princeton University Press.

. 1982. Consequences of Pragmatism: Essays: 1972-1980. Minneapolis: University of Minnesota Press.

. 1985. "Habermas and Lyotard on Postmodernity." Pp. 161-75 in Habermas and Modernity, edited by Richard J. Bernstein. Cambridge: MIT Press.

. 1987. "Pragmatism and Philosophy." Pp. 26-66 in After Philosophy, edited by Kenneth Baynes, James Bohman, and Thomas McCarthy. Cambridge: MIT Press. 
Ste. Croix, G. E. M. de. 1981. The Class Struggle in the Ancient Greek World. Ithaca: Cornell University Press.

- 1984. "Class in Marx's Conception of History, Ancient and Modern." New Left Review 146:94-111.

Schluchter, Wolfgang. 1979. "The Paradox of Rationalization: On the Relation of Ethics and World." Pp. 11-64 in Max Weber's Vision of History, by Guenther Roth and Wolfgang Schluchter. Berkeley and Los Angeles: University of California Press.

1981. The Rise of Western Rationalism. Berkeley and Los Angeles: University of California Press.

Schmid, Michael. 1982. "Habermas's Theory of Social Evolution." Pp. 162-80 in Habermas: Critical Debates, edited by John B. Thompson and David Held. Cambridge: MIT Press.

Schmidt, James. 1979. "Offensive Critical Theory? Reply to Honneth." Telos 39:6270.

Schroyer, Trent. 1975. The Critique of Domination. Boston: Beacon.

Sciulli, David. 1985. "The Practical Groundwork for Critical Theory: Bringing Parsons to Habermas (and vice versa)." Pp. 21-50 in Neofunctionalism, edited by Jeffrey C. Alexander. Beverly Hills: Sage.

- 1986. "Voluntaristic Action as a Distinct Concept: Theoretical Foundations of Societal Constitutionalism." American Sociological Review 51:743-66.

Shaw, William H. 1978. Marx's Theory of History. Stanford: Stanford University Press.

Sherover-Marcuse, Erica. 1986. Emancipation and Consciousness. New York: Basil Blackwell.

Sullivan, William M. 1982. Reconstructing Public Philosophy. Berkeley and Los Angeles: University of California Press.

Tenbruck, Friedrich H. 1980. "The Problem of Thematic Unity in the Works of Max Weber." British Journal of Sociology 31:316-51.

Thompson, John B., and David Held. 1982. Habermas Critical Debates. Cambridge: MIT Press.

Vidich, J. Arthur, and Stanford M. Lyman. 1985. American Sociology. New Haven: Yale University Press.

Walzer, Michael. 1965. The Revolution of Saints: A Study in the Origins of Radical Politics. Cambridge: Harvard University Press.

Weber, Max. [1930] 1958a. The Protestant Ethic and the Spirit of Capitalism, translated by Talcott Parsons. New York: Scribner's.

- [1915] 1958b. "Religious Rejections of the World and Their Directions." Pp. 323-59 in From Max Weber, edited and translated by H. H. Gerth and C. Wright Mills. New York: Oxford University Press.

- [1921] 1968. Economy and Society, vol. 1. Edited by Guenther Roth and Claus Wittich. New York: Bedminister.

Wellmer, Albrecht. 1985a. "Reason, Utopia, and the Dialectic of Enlightenment." Pp. 35-66 in Habermas and Modernity, edited by Richard J. Bernstein. Cambridge: MIT Press.

- 1985b. "On the Dialectic of Modernism and Postmodernism." Praxis International 4:337-62.

Whitebook, Joel. 1985. "The Politics of Redemption." Telos 63:156-68.

. 1986. "Autonomy and Redemption: Reply to Gonzales, Breines, and Wolin." Telos 69:146-57.

Wolin, Richard. 1984/1985. "Modernism vs. Postmodernism." Telos 62:9-29.

. 1985. "Against Adjustment." Telos 65:158-63.

. 1987. "Critical Theory and the Dialectic of Rationalism." New German Critique 41:23-52. 